\title{
The Flammarion Astronomical Society of Montpellier
}

Jean-Michel Faidit

24 av. de la République, F-30190 St. Chaptes, France

The Flammarion Astronomical Society of Montpellier was founded in 1902 and remained very active until 1923 , when the death of certain prominent members, precipitated its own demise. An observatory in the Tour de la Babote was opened in 1903 but fell into disrepair in the 1920s. One prominent member was Marcel Moye, who on his death in 1939, left his instruments to the S.A.F., accompanied by the sum of $100000 \mathrm{Fr}$, half of which was used to endow an award for young astronomers.

\section{A Decade of Organized Work in Venezuela}

\section{Domingo Sanchez}

Sociedad de Astronomía Guri, Apartado 368, Puerto Ordaz 8015-A, Venezuela

In 1978 Venezuelan amateur astronomers decided to meet yearly to provide a forum for the exchange of ideas and discussion of observing programmes. The contribution summarized the ten years of work and the papers that had been presented to the meetings.

[Text not received - Eds.]

[Public observatories and the use of professional facilities by amateurs were described by four participants. - Eds.]

\section{The Bochum Observatory}

J.V. Feitzinger, M. Hünerbein, R. Kordecki, G. Monstadt, and J. Prölss

Ruhr-Universität Bochum, Astronomisches Institut, Postfach 102148, D-4630 Bochum 1, Fed. Rep. of Germany

The various units of this observatory consist of a planetarium - which has a complex computer-controlled system - the programmes for which are varied with different degrees of astronomical information and entertainment value; observing stations with $12.5,40$, and $60-\mathrm{cm}$ instruments, used for regular public observing nights, special events, and special programmes for young children and their parents as well as specific older groups; a mobile observatory with a $32-\mathrm{cm}$ telescope; and a series of astronomical courses. 